\title{
PENULIS DAN MAKNA PUISI ANAK \\ DALAM HARIAN KOMPAS MINGGU*
}

\author{
oleh Burhan Nurgiyantoro \\ FBS Universitas Negeri Yogyakarta
}

\begin{abstract}
The view that poetry is one means of expressing various ideas, thoughts, and feelings applies on both adult poetry and poetry for children, which is nowadays increasingly written and published in, among others, magazines and newspapers. Today such poetry is also written by children themselves. A study on sixty-five poems for children sampled from the Kompas daily Sunday editions of 2005 has revealed that almost all of the poetry has been written by children, with $3.1 \%, 78.5 \%$, and $9.2 \%$ of them being, respectively, kindergarten, elementary school, and junior high school children (though another $9.2 \%$ of them are unidentifiable).

The themes of the poems are quite various and all reflect the world of children revealed through their point of view. However, there are certain recurring themes: nature and the environment, parents and teachers, and animals, all of which indicate children's closeness to them. Other themes also found are, among others, sports and toys, others' good deed, religiosity, money saving, and honesty. Generally the tone is didactic though the child writer means to invite or urge to do something. It indicates the children's innocence and directness of mind and way of thinking. Their teachers at school or their parents at home often tell them directly to do something and they just re-express it in the same manner. In poetic aspects, a number of the poems seem good enough but a part of the others still do not seem to be already well processed, especially in terms of word choice.
\end{abstract}

Keywords : children's literature, children's poetry, child writer, themes of children's poetry

\section{A. PENDAHULUAN}

Jika selama ini sastra anak terkesan diabaikan, perhatian orang terhadapnya kini semakin meningkat. Sastra anak diyakini mampu sebagai salah satu faktor yang dapat dimanfaatkan untuk "mendidik" anak lewat bacaan. Sastra anak diyakini mampu memberikan berbagai kemanfaatan untuk menyertai anak dalam proses kehidupan menuju kedewasaan. Dari berbagai manfaat sastra anak bagi anak, tampaknya hal yang tidak dapat diabaikan adalah perannya untuk membiasakan anak agar mau membaca. Singkatnya, sastra anak dapat dipergunakan sebagai salah satu sarana untuk menanamkan literasi membaca sehingga kebiasaan membaca dapat terinternalisasikan di dalam diri anak.

Genre sastra anak mencakup berbagai jenis yang antara lain adalah cerita fiksi, puisi, bacaan nonfiksi, dan komik. Keempat genre

\footnotetext{
* Artikel ini ditulis berdasarkan sebagian dari hasil penelitian yang berjudul Genre Sastra Anak di Harian Kompas Minggu, 2006.
} 
tersebut secara rutin dapat ditemukan dalam harian Kompas edisi Minggu yang secara khusus menyediakan lembar untuk anak yang bernama "Kompas Anak" yang berjumlah empat halaman. Hal itu menunjukkan bahwa penyediaan bacaan anak dipandang sebagai sebuah keharusan karena anak pun, sebagaimana halnya orang dewasa, juga berhak untuk memperoleh bacaan yang baik. Jika Kompas "berani" menampilkan lembar anak sebanyak empat halaman secara rutin, itu pasti menunjukkan bahwa lembar tersebut berterima di masyarakat dan juga dibaca oleh pembaca, bukan saja oleh anak, yang lebih luas.

Penulisan ini diangkat dari penelitian terhadap pemuatan genre sastra anak di Kompas edisi Minggu selama tahun 2005. Tujuan penelitian dan penulisan ini adalah untuk mendeskripsikan para pengarang puisi anak dan makna atau tema yang dikandung di dalamnya.

Penelitian dilakukan dengan mengambil sampel selama dua belas bulan penerbitan, yaitu mulai bulan Januari sampai Desember. Tiap bulan diambil dua atau tiga kali penerbitan, dan tiap penerbitan diambil dua buah puisi -kecuali hanya ada sebuah puisi dalam sebuah penerbitan- yang kesemuanya diambil secara purposif. Jumlah puisi yang dimuat tiap kali penerbitan berkisar antara satu sampai empat buah. Sampel puisi yang dikaji dalam penelitian ini adalah sebanyak 65 buah yang diambil dalam 33 kali penerbitan.

\section{B. SEKILAS TENTANG PUISI ANAK}

Sastra anak menurut Huck dkk. (1987:6) adalah children's books are books that have the child's eye at the center, buku anak, sastra anak, adalah buku yang menempatkan sudut pandang anak sebagai pusat penceritaan. Atau, yang menurut Saxby (1991:4) adalah bacaan yang mengisahkan citraan dan atau metafora kehidupan yang berada dalam jangkauan anak, baik yang melibatkan aspek emosi, perasaan, pikiran, saraf sensori, maupun pengalaman moral, dan diekspresikan dalam bentuk-bentuk kebahasaan yang juga dapat dijangkau dan dipahami oleh pembaca anak- anak. Di pihak lain, Lukens (2003:9) mengemukakan bahwa sastra anak adalah sebuah kebenaran yang signifikan yang diekspresikan ke dalam unsur-unsur yang layak dan bahasa yang mengesankan. Puisi anak sebagai salah satu genre sastra anak tentunya juga memiliki karakteristik tersebut.

Puisi adalah sebuah genre sastra yang amat memperhatikan pemilihan aspek kebahasaan sehingga tidak salah jika dikatakan bahwa bahasa puisi adalah bahasa yang "tersaring" penggunaannya. Artinya, pemilihan bahasa itu, terutama aspek diksi, telah melewati seleksi ketat, dipertimbangkan dari berbagai sisi baik yang menyangkut unsur bunyi, bentuk, dan makna yang kesemuanya harus memenuhi persyaratan untuk memperoleh efek keindahan. Unsur kebahasaan itu sendiri merupakan unsur bentuk, maka unsur bentuk dalam puisi menentukan keberhasilan sebuah puisi yang bersangkutan untuk menjadi puisi yang bernilai literer. Dengan kata lain, keberhasilan sebuah puisi tergantung dari keberhasilan pemilihan kata dan susunan kata itu menjadi larik-larik puisi (Nurgiyantoro, 2005:312).

Bahasa dalam puisi lebih didayagunakan sehingga mampu memberikan efek lebih dibandingkan dengan bahasa bukan puisi: lebih menyentuh, mempesona, merangsang, menyaran, membangkitkan imaji dan suasana tertentu, membangkitkan analogi terhadap berbagai hal, dan lain-lain. Itu semua dapat terjadi karena puisi lebih banyak mendayakan pengekspresian lewat berbagai ungkapan kebahasaan seperti berbagai bentuk pemajasan, terutama metafora dan simile, pencitraan, dan "permainan" bentuk-bentuk kebahasaan yang lain. Pengekspresian gagasan yang diungkapkan lewat berbagai bentuk pemajasan tersebut menyebabkan makna puisi menjadi lebih luas, "tidak terhingga", atau paling tidak dari sebuah puisi dapat ditafsirkan banyak makna. Pendayaan ekspresi ide-ide lewat berbagai bentuk metaforis itu pada hakikatnya juga berarti memberikan peluang kepada pembaca untuk menafsirkan makna lebih dari sekadar apa yang tersurat. 
Apa yang dikemukakan di atas lebih tepat untuk mencandra karakteristik puisi dewasa walau juga tidak salah untuk puisi anak. Hanya saja, untuk puisi anak intensitas keluasan makna itu tampaknya belum seluas puisi dewasa, paling tidak dari kacamata pemahaman orang dewasa, karena daya jangkau imajinasi anak dalam hal pemaknaan puisi masih terbatas. Demikian juga kemampuan anak dalam hal penggunaan dan pendayaan bahasa. Dilihat dari segi pendayaan berbagai bentuk ungkapan kebahasaan, puisi anak tentunya masih lebih sederhana. Kesederhanaan itu haruslah dilihat dari unsur diksi, struktur, ungkapan, dan kemungkinan pemaknaan. Puisi anak, baik dalam hal bahasa maupun makna yang diungkapkan masih polos, lugas, apa adanya. Namun, dilihat dari segi "permainan" bahasa, bahasa puisi anak terlihat lebih intensif. Hal itu terlihat dari pengutamaan kemunculan aspek rima dan irama atau berbagai bentuk pengulangan yang lain.

Puisi anak juga memiliki karakteristik yang identik dengan sastra anak: pengungkapan sesuatu dari kacamata anak. Sebagaimana halnya dengan puisi dewasa, puisi anak juga ditulis dengan seleksi kata yang ketat, pendayaan metafora dan citraan untuk menggambarkan imajinasi, memori, dan emosi (Mitchell, 2003:142). Namun, seleksi bahasa dan pendayaan berbagai ungkapan, citraan, serta berbagai penggambaran itu masih sebatas daya jangkau anak. Baik puisi dewasa maupun anak juga sama-sama berbicara tentang kehidupan, namun berbeda dalam hal melihat dan menanggapi kehidupan itu karena memang berbeda sudut pandangnya. Dalam puisi anak aspek emosi selalu sejalan dengan cerapan indera (Huck dkk, 1987:395). Artinya, berbagai luapan emosi anak dipengaruhi oleh tanggapan inderanya terhadap sesuatu yang ada di sekeliling karena daya jangkau imajinasi anak masih terbatas. Namun, puisi anak pun dapat dipakai untuk menyampaikan cerita.

Penulis puisi anak dapat siapa saja, tetapi mesti menyadari bahwa puisi itu sengaja dikonsumsikan kepada anak. Dengan demikian, persyaratan sebagai sastra anak, yaitu yang menempatkan sudut pandang anak sebagai pusat penceritaan, haruslah terpenuhi. Selama ini terkesan bahwa penulis sastra, termasuk sastra anak, tentulah orang dewasa. Namun, pandangan itu kini mulai dapat dipatahkan karena pada kenyataannya banyak anak usia sekolah dasar yang sudah mampu menulis puisi dan cerita fiksi anak. Penulisan ini juga dimaksudkan untuk menunjukkan bahwa para pengarang puisi anak yang dimuat di Kompas Minggu adalah anak-anak.

\section{ANAK SEBAGAI PENULIS PUISI ANAK}

Sampai usia berapakah seorang bocah masih dapat disebut sebagai anak? Jawaban terhadap pertanyaan itu sebenarnya tidak dapat eksak karena pendapat di antara para tokoh tidak selalu sama. Selain itu, perkembangan anak-anak sendiri sering menunjukkan adanya perbedaan. Namun demikian, sebagai acuan secara umum tampaknya dapat dikemukakan sebagai berikut.

Huck dkk. (1987:64-72) membagi buku-buku yang cocok untuk bacaan anak yang sesuai dengan tiap tahapan usia anak, dan tahapan usia anak itu sendiri dibedakan ke dalam tahap-tahap: (1) sebelum sekolah\%masa pertumbuhan, usia 1-2 tahun, (2) prasekolah dan taman kanak-kanak, usia 3, 4, dan 5 tahun, (3) masa awal sekolah, usia 6 dan 7 tahun, (4) elementari tengah, usia 8 dan 9 tahun, dan (5) elementari akhir, usia 10, 11, dan 12 tahun. Jadi, berdasarkan pembagian Huck dkk. di atas, yang dapat dikategorikan sebagai anak adalah anakanak usia 1 hingga kurang lebih 12 tahun.

Piaget (via Brady, 1991:28-30) membagi perkembangan intelektual anak ke dalam empat tahapan, dan tiap tahapan mempunyai karakteristik yang berbeda yang mempunyai konsekuensi pada respons anak terhadap bacaan. Keempat perkembangan intelektual itu adalah: (1) tahap sensori-motor (the sensory-motor period, 0-2 tahun), (2) tahap praoperasional (the preoperational period, 2-7 tahun), (3) tahap operasional konkret (the concrete operational, 7-11 tahun), dan (4) tahap operasi formal (the formal 
operational, 11 atau 12 tahun ke atas). Dengan demikian, orang yang dapat dikategorikan sebagai anak itu adalah orang yang berusia 0 tahun sampai dengan sekitar 12 tahun. Jadi, anak yang dimaksudkan dalam sastra anak itu adalah orang yang berusia 0 tahun sampai sekitar 12 atau 13 tahun, atau anak yang sudah masuk dalam masa remaja awal.

Tingkat sekolah atau usia para penulis puisi anak di Kompas Minggu yang dikaji dalam penulisan ini secara lengkap dapat dilihat pada Tabel 1 di bawah ini.

Tabel 1: Para Pengarang Puisi Anak dilihat dari Tingkat Sekolah

\begin{tabular}{|c|c|c|c|}
\hline No. & Tingkat Sekolah & $\begin{array}{c}\text { Frekuensi } \\
\text { (Persen) }\end{array}$ & Keterangan \\
\hline 1 & TK & $2(3,1)$ & \\
\hline \multirow[t]{3}{*}{2} & \multirow[t]{3}{*}{$\mathrm{SD}$} & \multirow[t]{3}{*}{$51(78,5)$} & Kelas 1-3:29(44,62) \\
\hline & & & Kelas 4-6 : $18(27,7)$ \\
\hline & & & Tidak Jelas (hanua ditulis SD saja) : $4(9,2)$ \\
\hline \multirow[t]{2}{*}{3} & \multirow[t]{2}{*}{ SMP } & \multirow[t]{2}{*}{$6(9,2)$} & Kelas $1: 4(6,2)$ \\
\hline & & & Kelas $2 \quad: 2(3,1)$ \\
\hline 4 & $\begin{array}{l}\text { Tidak Jelas (Tidak } \\
\text { disebutkan usia } \\
\text { atau sekolahnya) }\end{array}$ & $6(9,2)$ & $\begin{array}{l}\text { Jika dilihat dari segi gaya dan nama, } \\
\text { tampaknya mereka masih anak-anak sekolah } \\
\text { SD atau SMP }\end{array}$ \\
\hline
\end{tabular}

Penulis puisi anak yang dimuat di Kompas edisi Minggu sebagian besar adalah anak SD $(78,5 \%)$, sebagian yang lain anak SMP dan TK serta penulis yang tidak lengkap identitasnya. Hal yang lebih mengagumkan adalah bahwa anak SD kelas 1-3 lebih banyak daripada yang kelas 4-6, dan bahkan terdapat dua penulis $(3,1 \%)$ yang masih di TK. Dengan melihat tabel di atas, tampaknya boleh dikatakan bahwa penulis puisi anak yang dimuat di Kompas Minggu hampir semuanya anak-anak. Kenyataan itu memperlihatkan bahwa anak-anak tingkat SD sudah mengenal sastra dan bahkan sudah pula mampu menghasilkannya. Hal itu juga menunjukkan bahwa penulis sastra anak, yang dalam hal ini adalah genre puisi, tidak harus orang dewasa, melainkan juga anak-anak. Mereka, anak-anak yang mengagumkan dan menjanjikan itu, sudah mampu mengekspresikan gagasan, pikiran, dan perasaannya lewat media puisi yang dikenal sebagai salah genre sastra.

Karena mereka masih anak-anak, di samping juga jangkauan makna sebagaimana terlihat di bawah masih berada dalam wilayah dunia anak-anak, karya yang dihasilkan adalah berkategori sastra anak. Karya puisi yang dihasilkan pun tidak mengecewakan, polos, lugu-lugas, tetapi sudah memperlihatkan kecakapan anak-anak itu bermain dengan bahasa untuk membangkitkan efek puitis. Terhadap kenyataan adanya dua anak TK, atau kelas I SD, yang sudah mampu menulis puisi, kita tidak perlu berpikir bahwa puisi itu sengaja dibuatkan oleh orang lain, walau kemungkinan itu juga bukan hal yang mustahil untuk penulisan unsur tertentu. Misalnya, dalam hal menulis dalam format puisi dan ejaan.

\section{MAKNA PUISI ANAK DI HARIAN KOMPAS MINGGU}

Sebuah puisi hadir karena orang ingin berekspresi mengekspresikan apa yang terkandung di dalam jiwanya ke dalam bahasa yang khas: singkat, padat, ekspresif, dan puitis. Masalah yang diekspresikan mencakup berbagai persoalan hidup dan kehidupan yang menyentuh dan mendorong jiwa secara masif yang menuntut rasa untuk dilontarkan. Itulah sebabnya gagasan yang dikandung oleh puisi 
pun dapat beragam seberagam persoalan kehidupan yang dihadapi oleh manusia, tidak terkecuali oleh seorang anak.

Anak pun sudah mempunyai dorongan kejiwaan untuk berekspresi mengekspresikan berbagai persoalan kehidupan yang dialami. Maka, lahirlah puisi-puisi anak yang memang ditulis oleh anak-anak. Jika penulis puisi anak (hampir) semuanya masih berstatus anak-anak, apa makna yang ingin disampaikan kepada pembaca yang mestinya juga anak? Yang jelas, apa pun yang disampaikan pastilah masih dalam jangkauan jiwa dan pengalaman anak.
Persoalan yang diungkap pun beragam, namun tetap saja mencerminkan dunia anak dan segala sesuatu yang masih dalam jangkauan jiwa anak. Hal itu mengindikasikan, sekali lagi, bahwa anak pun sudah mempunyai dorongan untuk berekspresi ke dalam bahasa yang indah dan menyentuh.

Hasil kajian terhadap ke-65 buah puisi anak memperlihatkan bahwa tema alam dan orang tua masih mendomansi makna puisi mereka. Secara lengkap hasil kajian yang dimaksud ditunjukkan pada tabel 4.2 berikut.

Tabel 4.2: Makna dan atau Tema Puisi Anak di Harian Kompas Minggu

\begin{tabular}{|c|c|c|c|}
\hline No. & Makna (Tema) yang Dikandung & $\begin{array}{l}\text { Frekuensi } \\
\text { Permunculan } \\
\text { (Persen) }\end{array}$ & Keterangan \\
\hline 1. & Alam dan lingkungan hidup & $18(27,7)$ & \multirow{7}{*}{$\begin{array}{l}\text { Satu puisi bisa saja } \\
\text { menawarkan dan atau } \\
\text { dapat dipahami } \\
\text { menawarkan lebih } \\
\text { dari satu makna, } \\
\text { tetapi dalam kaitan } \\
\text { ini hanya satu makna } \\
\text { yang didentifikasi }\end{array}$} \\
\hline 2. & Orang tua, guru, atau keluarga & $12(18,5)$ & \\
\hline 3. & Binatang & $8(12,3)$ & \\
\hline 4. & Olah raga dan mainan & $6(9,2)$ & \\
\hline 5. & Jasa orang lain & $4(6,1)$ & \\
\hline 6. & Religius & $3(4,6)$ & \\
\hline 7. & $\begin{array}{l}\text { Lain-lain : menabung, kejujuran, ulang } \\
\text { tahun, lomba mewarnai, minum susu, } \\
\text { pertemanan, cermin, peminta-minta, } \\
\text { dan lain-lain }\end{array}$ & $14(21,5)$ & \\
\hline \multicolumn{2}{|c|}{ Jum lah: } & $65(100)$ & \\
\hline
\end{tabular}

Sebagaimana yang terlihat pada Tabel 4.2 di atas, dari ke-65 buah puisi, makna atau tema puisi anak yang dikandung, tiga dari urutan terbanyak adalah (i) alam dan lingkungan hidup (27,7\%), orang tua, guru, atau orang tua $(18,5 \%)$, dan binatang $(12,3 \%)$. Hal itu mengindikasikan bahwa ketiga hal itulah yang paling banyak mewarnai pemikiran dan perasaan anak sehingga mendorong jiwanya untuk berekspresi tentangnya. Kita juga menjadi mengetahui bahwa ketiga hal itulah yang paling dekat dan menyentuh kejiwaan anak, atau sebaliknya masih terbatas pada ketiga hal itulah jangkauan utama pemikiran anak.
Tema alam dan lingkungan hidup adalah hal yang paling menarik perhatian anak, maka makna inilah yang terlihat paling banyak ditemukan dalam puisi-puisi anak yang ditulis oleh anak-anak. Tema alam dan lingkungan dapat berupa kekaguman atau candraan mengenai keindahan alam seperti berbagai bunga, tanaman, suasana alam yang cerah, embun pagi, pelangi, langit dan awan, laut, tetapi juga bisa berupa bencana alam seperti banjir dan tsunami. Misalnya, kekaguman Jessica Sibarani (SD kelas II) terhadap embun pagi pada puisinya yang berjudul "Embun" berikut. 


\section{EMBUN}

Setia pagi kubuka jendela

Ketika mentari pagi mulai bersinar

Burung-burung berkicau riang

Memuji sang Pencipta alam

Kulihat engkau selalu ada di sana

Di atas dedaunan

Berdiri anggun membasahi sang bunga

Bening, jernih... dan bersih

Menetes perlahan membasahi alam

Menyejukkan jiwa ... menyegarkan mata

Dan angin berembus mendesah

Menambah dinginnya udara

Kutanya Mama apa namanya

Wahai engkau si bening jernih

Engkaulah si embun pagi

Setia sepanjang masa

Menambah hidupku penuh warna

(Kompas, 4 September 2005)

Si bocah kelas II SD Jessica itu penuh kekaguman pada keindahan embun pagi yang selalu dilihat setiap pagi ketika membuka jendela: bening, jernih, bersih, meyejukkan jiwa, menyegarkan mata, dan menambah warna kehidupannya. Keindahan embun pagi yang setia sepanjang masa itu cukup menggetarkan jiwa Jessica, si bocah yang mudah tersenuh rasa keindahannya. Alam dan lingkungan hidup yang ada di sekitar anak yang berbagai-bagai macamnya setiap hari dijumpai sehingga tampaknya merupakan hal yang wajar jika anak lebih memperhatikan, mengagumi, dan kemudian mengekspresikan ketersentuhan jiwanya ke dalam puisi.

Selain embun pagi, lingkungan alam anak yang lain adalah bunga-bungaan. Tema bunga-bungaan juga relatif banyak diangkat ke dalam puisi anak oleh anak-anak sebagai salah satu wujud ketertarikannya. Hal itu misalnya terlihat pada puisi "Bunga Mawar" (Fadilla Adwina), "Bunga di Rumah Tetangga" (Ismi Alawiyah, SD Kelas V), dan Bunga Matahari" (Winoto, SD Kelas II). Secara lengkap puisi "Bunga Mawar" tersebut adalah sebagai berikut.

\author{
BUNGA MAWAR \\ Ketika fajar menyingsing \\ Kulihat dari kejauhan \\ Kau bunga mawarku \\ Merah warnamu bagaikan hati seorang ibu \\ Kusirami dengan penuh kesabaran \\ Tapi kau tetap menusuk jariku \\ Tapi aku akan selalu merawatmu
}

(Kompas, 4 Desember 2005)

Bagi si bocah Winoto, bunga mawar yang merah itu memiliki keindahan yang khas yang tidak saja indah dari segi warnanya saja, melainkan keindahan yang bersifat simbolis, keindahan hati seorang ibu. Hati seorang ibu bagi anak anak adalah segalanya: tempat curahan kasih sayang dan tidak pernah berhenti menyayangi, maka Winoto pun dengan penuh kesabaran selalu merawat dan menyirami tumbuhan bunga mawar itu. Pembandingan keindahan mawar merah dengan hati seorang ibu sebenarnya kurang lazim dilakukan, maka barangkali yang dimaksud Winoto adalah kelembutan hati seorang ibu itu seindah keindahan dan kelembutan bunga mawar.

Awan atau juga langit secara umum bagi (Keisha Alika Lie, SD Kelas II) anak, juga tidak kurang menarik. Langit dapat menyajikan bermacam pemandangan dan keindahan, misalnya ada burung-burung dan benda-benda seperti tiruan bunga dan domba yang kesemuanya itu membuat senang dan kagum. Langit dan awan pun bahkan dianggpnya sebagai makhluk hidup, maka Keisha ingin awan tidak pergi dari dunia serta ingin bersahabat dan berbicara dengan awan. Hal itu diungkapkannya dalam puisi "Awan" sebagai berikut.
AWAN
Awan yang indah
Burung-burung beterbangan
Awan bisa membuat kita senang
Aku suka melihat awan
Yang berwarna biru
Ada sebagian berwarna putih 


\author{
Awan itu indah \\ Indah seperti bunga \\ Sampai aku bisa melihat domba \\ Di awan yang tinggi di sana
}

Awan, janganlah pergi dari dunia

Aku suka melihatmu, awan

Awan, aku mau menjadi temanu

Tolong jawab aku

Sebenarnya aku ingin semua awan bicara

(Kompas, 30 Oktober 2005)

Makna kedua puisi-puisi anak yang tinggi frekuensi pemunculannya adalah orang tua, guru, dan keluarga. Tema-tema puisi yang berkaitan dengan hal-hal tersebut menunjukkan adanya keterkaitan emosional antara anak dengan mereka. Mereka itulah yang secara faktual berjasa membentuk kepribadian anak baik lewat kasih sayang, pemberian-pemberian, pendidikan, perhatian, perawatan, dan lain-lain yang kesemuanya amat mengesankan bagi emosi anak. Oleh karena itu, kepada merekalah anak-anak ingin mempersembahkan hatinya yang terekspresi lewat puisi-puisi yang ditulis. Jika puisi dapat dipandang sebagai luapan jiwa, hati, perasaan, dan pikiran anak, hal-hal itu semua dapat terlihat lewat puisi-puisi tentang bagaimana tanggapannya kepada orang-orang yang berjasa tersebut.

Bagi anak seorang ibu adalah sosok yang amat baik, baik secara fisik maupun hati. Kebaikan hati seorang ibu amat mengesan dan membahagiakan anak. Di bawah ini ditunjukkan dua buah puisi yang sama-sama ditulis oleh bocah SD kelas satu (Keumala Cahaya dan Adzhani Khairana Putriperdana) yang memperlihatkan reaksi dan sikap mereka terhadap kiprah ibu-ibu mereka.

\section{MAMA TERSAYANG}

Oh, Mama engkau bagaikan sebuah melodi Yang mendendangkan lagu sayang untukku Saat aku sedang sakit, engkau memelukku

\author{
Aku merasakan pelukanmu sangat hangat \\ Bagaikan perapian yang menghangatkanku \\ Di saat adikku menangis, engkau \\ menggendongnya \\ Waktu aku kecil engkau menggendongku \\ Tapi sekarang tidak \\ karena aku sudah besar1
}

(Kompas, 18 Desember 2005)

\section{IBUKU SAYANG, KEREN, DAN OKE}

Ibuku cantik sekali wajahnya berseri-seri

Kalau aku sedih dia menghiburku

Ibuku baik hati, aku dirawat setiap hari

Makanku selalu dijaga, uang saku itu pasti

Ibuku suka bercerita, ceritanya selalu menarik hati

Aku senang mendengarnya

hingga tertidur dibuatnya

(Kompas, 18 Desember 2005)

Pilihan bahasa dan kata-kata yang sederhana pada kedua puisi tersebut menunjuk kesederhanaan dan kepolosan jiwa anak-anak yang mengungkapkannya yang memang baru kelas satu SD. Bagi anak seusia itu, ibu adalah sebagai pusat dunianya: ibulah yang mendengkan lagu sayang, yang memeluk ketika sedang sakit, yang menggendongnya, dan yang menghangatkannya bagai perapian bagi Keumala. Bagi Adzhani, ibu tidak saja cantik sekali dan berseri-seri, tetapi juga merawat setiap, menghibur ketika sedih, menjaga apa yang dimakan, mendongeng cerita sampai ia tertidur, dan pasti memberi uang saku sekolah.

Selain sosok seorang ibu, tokoh lain yang juga banyak menjadi obsesi anak-anak adalah guru. Guru adalah orang tua kedua, ibu kedua, bagi anak, maka guru pulalah yang mampu menyentuh jiwa anak untuk kemudian diekspresikan ke dalam puisi. Dalam hal ini tampaknya tidka berlebihan jika dikatakan bahwa tokoh-tokoh tersebut, yaitu ibu, guru, dan keluarga, adalah tokoh-tokoh yang dipersembahi puisi oleh anak-anak yang merasa amat dijasa oleh mereka. Lewat puisi 
persembahan itu tampaknya anak ingin mengabadikan jasa mereka sebagai salah satu ucapan rasa terima kasih. Oleh karena itu, terlihat puisi-puisi persembahan itu terasa massif, ekspresif, dan sekaligus menyentuh dan mengharukan. Di bawah ini dicontohkan dua puisi anak tentang guru yang ditulis oleh Erwita Danu Gondo Hutami (SD) dan Rara Tyas Dwi Karina (SD kelas V).

\section{GURUKU PAHLAWANKU \\ Oh guruku... \\ Engkaulah pahlawan diriku \\ Engkaulah pelita hatiku \\ Trima kasih tlah kuucapkan}

Oh guruku...

Kau dambaanku

Kau beri teladan

Kau sabar bagai bidadari

Hatimu tulus ikhlas

Mendidik kami agar pandai

Engkau pahlawan Negara

Biarpun tanpa tanda jasa

(Kompas, 11 September 2005)

\section{GURUKU PAHLAWANKU}

Jasamu sangat mulia

Mengajar murid agar pintar

Kau mengajari aku membaca

Kau mengajari aku menulis

Dan kau juga mengajari aku menghormatimu

Kau mengajari aku hingga aku bisa

Oh guru...

Kau adalah pahlawan tanpa tanda jasa

Terima kasih guru atas jasamu

(Kompas, 27 November 2005)

Begitu mulia sosok seorang guru bagi kedua bocah tersebut. Bagi keduanya, guru diakuinya amat berjasa mendidik dan memintarkannya. Bagi Erwita guru adalah pelita hati, pemberi teladan, dambaan, dan sabar bagaikan bidadari (tapi kita tidak tahu dari mana Erwita dapat menyimpulkan bahwa bidadari itu berwatak sabar dan bukannya cantik saja). Guru adalah pahlawan Negara walau diakui keduanya pahlawan tanpa tanda jasa. Namun, apa pun ekspresi mereka tentang guru, terlepas apakah pembandingannya tepat atau tidak, guru adalah sosok amat berharga, dihormati, dan begitu menyentuh hati dan perasaannya. Lahirnya puisi ini tampak didorong oleh luapan hati yang masif yang ingin mengakui jasa dan sekaligus menyampaikan rasa terima kasih itu kepada guru.

Selain kedua orang tua, guru adalah orang yang setiap hari dijumpai oleh anak-anak yang secara kasat terlihat usaha dan perjuangan guru untuk mendidik dan mengajarkan ilmu kepada mereka. Peran orang tua untuk mendidik anak-anak, di sekolah hal itu diambil alih oleh guru. Kata-kata guru pada umumnya amat didengarkan dan dipercaya oleh anak. Bagi mereka, guru adalah sosok yang luar biasa pintar dan berjasa. Begitu percayanya anakanak kepada guru, maka sering terlihat dalam hal tertentu, misalnya dalam hal pelajaran, anak tidak mempercayai orang lain termasuk orang tuanya. Misalnya, ketika anak mendapat tugas rumah untuk mengerjakan latihan dan bantuan orang tua tidak seperti yang ditunjukkan oleh guru, anak dengan serta-merta menyalahkannya.

Tema selanjutnya yang relatif banyak diangkat oleh anak-anak ke dalam puisi adalah masalah binatang. Jenis-jenis binatang tertentu ada disekitar anak, maka tidak mengherankan jika anak kemudian merasa dekat hatinya terhadap binatang-binatang itu. Kedekatan hati anak terhadap sesuatu dalam banyak hal dipengaruhi oleh kedekatan sesuatu tersebut kepada anak, dekat dalam arti yang sesungguhnya. Artinya, secara fisik anak memang dapat bersentuhan secara indrawi terhadapnya. Binatang-binatang seperti kucing, ayam, anjing, kupu-kupu, binatang ternak, merpati atau burung, dan lain-lain adalah contoh binatang-binatang yang dekat secara fisik kepada anak. Bagi anak desa, pada 
umumnya binatang ternak seperti ayam, kambing, dan lembu adalah binatang-binatang yang lebih dekat, sedang anak-anak perkotaan misalnya kucing, anjing, adan burung yang terlihat lebih dekat. Karena kedekatannya itulah anak tersentuh hatinya untuk berekspresi dalam bentuk puisi terhadap binatang-binatang tersebut.

Dua buah puisi yang dicontohkan di bawah ini adalah tentang burung merpati yang masing-masing ditulis oleh Ashilly Achidsti (SD Kelas III) dan Quratu Aini (SD Kelas VI).

\section{BURUNG MERPATI}

Bulu putih seperti salju

Suara merdu merayu

Kau mengepakkan sayapmu kemari ke sana

Terbang tinggi meraih angkasa

Burung merpati

Sangatlah anggun

Seakan selalu tersenyum santun

Kepada semua orang yang melewati

Kuingin terbang bersamamu

Meraih angkasa

(Kompas, 11 Desember 2005)

\section{BURUNG MERPATI}

Saat kubuka jendela di pagi hari

Kulihat seekor burung merpati

Tergeletak tak bisa berdiri

Dengan luka peluru di sayap kiri

Wahai burung merpati

Betapa malang nasibmu

Ditembak pemburu yang tak tau diri

Yang hanya memikirkan kepentingan sendiri

Wahai burung merpati

Bertahan hiduplah sebentar di tanahku ini

Aku akan masuk mengobati

Agar kau bisa terbang kembali

(Kompas, 17 Juli 2005)
Kedua puisi di atas sama-sama berjudul "Burung Merpati", namun apa yang diungkapkan oleh kedua anak itu tidak sama. Kedua anak itu sama-sama tertarik untuk berpuisi tentang burung merpati, namun sesuatu yang menyentuh hati yang mendorong untuk kemudian mengekspresikan berbeda. Ashilly menulis untuk mengekspresikan perasaan kagum pada keindahan merpati yang mempunyai "Bulu putih seperti salju", "Suara merdu merayu", dan mampu "Terbang tinggi meraih angkasa". Bagi ashilly, burung merpati itu dapat tersenyum santun kepada manusia, dan ia ingin dapat terbang bersamanya. Keinginan yang wajar dari seorang bocah berusia delapan tahun yang bisa berimajinasi termasuk yang tidak masuk akal sekalipun.

Di pihak lain, Quratu tersentuh hainya pada burung merpati bukan karena keindahan, melainkan karena rasa perikebinatangan yang melihat seekor burung tergeletak tidak terbag karena terluka. Jadi, rasa sayang pada sesama makhluk hidup lebih dominan daripada yang lain dan ia merasa harus mengobati makhluk yang terluka tersebut. Quratu juga terlihat menyesalkan penembak yang tidak bertanggung jawab, semena-mena, dan hanya memikirkan kepentingan sendiri. Sikap Quratu tersebut dapat juga disebabkan pada umumnya anak menyukai binatang, apalagi binatang yang indah dan jinak seperti merpati, maka jika binatang itu terluka ia akan berusaha mengobatinya.

Kucing juga merupakan salah satu binatang yang dekat dan disukai oleh pada umumnya anak-anak. Puisi "Kucingku Sayang" karangan Sleska Dewi Sumendap (SD Kelas VI) di bawah ini adalah salah satu contohnya.

$$
\begin{gathered}
\text { KUCINGKU SAYANG } \\
\text { Kupanggil kau Puci } \\
\text { Lengkapnya Puci Miaw } \\
\text { Warna bulumu putih dan hitam } \\
\text { Dengan kumis yang menjuntai }
\end{gathered}
$$


Setiap hari kau kuberi makan

Tak lupa juga kuberi minum

Tiap pagi kuajak bermain

Berlari-lari

Sekarang kau sudah tak ada lagi

Diambil pamanku, dibuang ke desa

Bukan maksudku melakukan hal yang

Menusuk hati nurani

(Kompas, 6 Maret 2005)

Dunia anak adalah dunia bermain. Artinya, berbagai aktivitas anak lebih banyak yang menurut kacamata orang dewasa adalah bermain-main. Dalam permainan itu terkandung di dalamnya olah raga. Bagi anak bermain-main dan olah raga adalah dua hal yang sulit dibedakan: permainan fisik seperti kejar-kejaran, naik sepeda, dan mengejar layang-layang putus sebenarnya adalah juga olah raga. Di pihak lain, bermain bola seperti sepak bola dan bola basket atau voli, yang sebenarnya dapat dikategorikan olah raga, bagi anak-anak kegiatan itu adalah bermain. Tema olah raga dan bermain adalah makna yang ditemukan dalam puisi anak-anak yang juga ditulis oleh anak-anak. Olah raga dan bermain atau bermain dan olah raga adalah sesuatu yang juga mampu menyentuh jiwa anak sehingga beberapa di antara mereka kemudian mengekspresikannya dalam bentuk puisi.

Puisi-puisi tentang olah raga yang lebih sering ditemukan adalah bermain bola, khusunya bermain sepak bola. Namun demikian, hal itu bukannya pada diri anak belum tertanam konsep bahwa olah raga yang menyebabkan tubuh menjadi sehat karena anak pun sudah menyadarinya. Hal itulah yang diungkapkan oleh Fajar laksana (SD kelas III) tentang olah raga. Menurut Fajar, yang senang olah raga itu, olah raga disukai banyak orang karena membuat badan menjadi sehat. Inilah puisi "Olahraga" secara lengkap karangan Fajar yang dimaksud.

\author{
OLAHRAGA \\ Olahraga membuat badan sehat \\ Serta juga kuat \\ Banyak orang suka olahraga \\ Olahraga bisa dilaksanakan setiap harui
}

Seperti olahraga sepakbola

Berlari berebut bola

Aku suka olahraga

Karena tubuhku jadi sehat

(Kompas, 29 Mei 2005)

Walau masih dalam "dunia bermain", tidak sedikit juga anak yang sudah mulai peka pada keadaan sekelilingnya yang biasa dijumpai dalam kehidupan sehari-hari. Artinya, mereka mulai dapat berpikir serius tentang kehidupan dan menyadari bahwa dalam hidup ada sesuatu yang lain selain bermain. Anak tidak hanya menyadari adanya kehidupan social yang lain selain diri dan kawannya bermain yang perlu mendapat perhatian. Lewat kegiatan bermain dengan kawannya itu anak akan memperoleh kesadaran bersosial, dan kehidupan bersosial juga dapat diperoleh lewat interaksinya dengan orang lain.

Tema selanjutnya yang ditemukan pada puisi-puisi anak adalah masalah kesadaran dan apresiasi anak terhadap jasa yang diberikan oleh orang lain. Hal itu menunjukkan bahwa kesadaran sosial sudah lebih tinggi dan tidak lagi menonjolkan sifat egois dan egosentrisme. Sikap mau menghargai orang lain yang di luar "keluarga dekat' seperti orang dan guru dapat dipandang sebagai kesadaran tentang kemanusiaan, suatu hal yang amat dibutuhkan dalam kehidupan kelak. Misalnya, kesadaran untuk menghargai orang yang bekerja dengan tulus untuk kepentingan orang lain. Singkatnya, anak mau menghargai jasa orang yang amat bermanfaat bagi sesama. Hal itu termasuk sesuatu yang menyentuh hati anak, maka mereka mengekspresikannya ke dalam sebuah puisi. Dua hal tentang penghargaan terhadap jasa orang lain tersebut diungkap oleh Putri Hutami Ning Tyas (SD Kelas VI) lewat puisi "Pak Pos" 


\section{PAK POS}

Engkau mengayuh sepeda sepanjang jalan

Tak pandang panas maupun hujan

Untuk melaksanakan tugas harian

Miskin dan kaya tidak kau bedakan

Surat pada mereka kau berikan

Kring, kring, kring itu kodemu

Begitulah berjalan sepanjang waktu

(Kompas, 21 Agustus 2005)

Perasaan Putri tersentuh oleh ketulusan kerja Pak Pos yang hanya mengayuh sepeda sepanjang jalan, yang tidak menghiraukan panas atau hujan karena itu memang pekerjaannya, dan lebih dari itu, ia tidak membedakan orang kaya atau miskin. Ketersebtuhan terhadap kerja dan jasa orang lain lebih terasa lagi dalam puisi karya Aninda Yasmin Farhanah (SDS Kelas V) yang berjudul "Palang Merah".

Untuk dapat menulis puisi ini, setidaknya ada hal penting yang telah dilewati oleh Aninda. Pertama, ia telah mengetahui "apa dan bagaimana" itu Palang Merah, yaitu sebuah lembaga yang bergerak di bidang sosial dengan memberikan pertolongan kepada umat manusia yang berada dalam kesusahan yang berhubungan dengan darah, dan darah adalah urusan nyawa. Kedua, hatinya tersentuh oleh kenyataan bahwa ada orang yang mau berjuang demi nyawa orang lain tanpa imbalan apa pun kecuali niat untuk menolong sesama. Orang yang sudah mengikrarkan diri mau bekerja di palang Merah adalah orang yang mau membantu dan berkorban demi orang lain yang amat membutuhkan, orang yang mau menyelamatkan nyawa orang lain, dan semuanya itu haruslah dilakukan dengan tulus ikhlas. Terhadap adanya orang yang berprinsip begitu, kita haruslah menghargainya. Puisi itu tampaknya lahir karena adanya dorongan Aninda untuk menghargai jasa para pekerja Palang Merah yang mampu menyentuh hatinya. Puisi yang dimaksud secara lengkap ditunjukkan di bawah ini.

\author{
PALANG MERAH \\ Jika terjadi perang \\ Palang Merah sangat berjasa \\ Menolong orang-orang yang terluka \\ Tanpa imbalan apa-apa \\ Jika terjadi kecelakaan \\ Palang Merah selalu siaga \\ Memberi pertolongan \\ Tanpa imbalan apa pun \\ Sungguh mulia tugasmu \\ Wahai anggota Palang Merah \\ Besar sekali jasamu \\ Untuk membantu \\ Sesama umat manusia
}

(Kompas, 5 Juni 2005)

Ketersentuhan hati Aninda terhadap para pekerja Palang Merah mirip dengan ketersentuhan hati anak-anak kepada guru yang telah dengan ikhlas mengajar yang disebutnya sebagai sebagaimana ditunjukkan pada beberapa puisi sebelumnya. Kedua profesi itu, guru dan Palang Merah dikatakannya sebagai "Sungguh mulia tugasmu", "Besar sekali jasamu" dalam membantu sesama umat manusia. Dilihat dari segi nilai literernya pun puisi ini tidak mengecewakan terutama dalam hal mengungkapkan secara paralelistis ide-ide. Memang, tak dapat diingkari makna yang diungkapkan terasa "terlalu besar", apalagi dengan kata-kata yang juga terasa besar sehingga mengurangi kesederhanaan bahasa.

Puisi yang lebih sederhana baik dalam hal pemilihan kata, stile, maupun sikap yang diberikan terlihat pada puisi lain, yaitu karya Nadira Syahmifarisa (SD Kelas III) yang berjudul "Jasa Mereka". Kesederhanaan puisi Nadira justru memperkuat makna yang ingin disampaikan. Ia mencandra apa yang seharihari dilihat dan atau bersentuhan dengan kebanyakan orang termasuk dirinya, yaitu petani, nelayan, dan klimaksnya, orang tua kita. Kepada sosok-sosok mereka itulah Nadira melontarkan ketersentuhan hatinya dalam 
bentuk puisi terutama berwujud penghargaan mereka atas jasa-jasanya sesuai dengan profesinya. Namun, profesi mereka, baik petani maupun nelayan, apalagi orang tua kita, tetap saja bersentuhan dengan kebutuhan sehari-hari kita, maka kepada mereka haruslah diberi apresiasi. Kepada mereka semua kita mesti merasa berhutang budi baik secara langsung maupun tidak langsung. Secara lengkap puisi yang dimaksud berikut ditunjukkan.

\author{
JASA MEREKA \\ Lihatlah petani \\ Mereka telah berikan kita padi kuning berisi \\ Kita memakannya \\ Dengan lauk dan sayur \\ Lihatlah nelayan \\ Mereka telah memberikan ikan segar \\ Kita memakannya \\ Dengan nasi dan sayur \\ Tetapi hati-hati dengan tulangnya \\ Yang tajam di perut \\ Lihatlah orang tua kita \\ Berusaha mencari uang untuk makan \\ Dan sekolah kita \\ Jasa mereka sangat berarti bagi kita \\ Jasa mereka diberikan kepada kita \\ Susah payah mereka mencarinya \\ Pergunakanlah dengan sebaik-baiknya
}

Oh Tuhan, berikanlah imbalan untuk mereka

Berupa pahala dan nikmat yang cukup

(Kompas, 16 Oktober 2005)

Nadira tidak saja mengungkapkan hati untuk menghargai jasa mereka semua secara tulus, tetapi juga mendoakan agar diberi imbalan yang sesuai dengan jerih payahnya yang "Berupa pahala dan nikmat yang cukup". Doa kepada Tuhan yang juga merupakan salah satu cara untuk menghargai dan berterima kasih. Jadi, kalaupun tidak dapat membalas kebaikan mereka secara langsung, permohonan doa kepada Tuhan merupakan salah satu cara membalas kebaikan.

Dengan demikian, selain bermakna penghargaan atas jasa orang lain kepada kita, puisi Nadira ini juga sekaligus mengandung makna religius. Makna religius merupakan salah satu puisi anak yang juga ditemukan dalam penelitian ini walau tidak sebanyak makna alam dan orang tua. Namun, hal itu cukup menunjukkan bahwa masalah religius pun telah menjadi obsesi anak, telah mampu menyentuh jiwa anak sehingga mereka terdorong untuk mengekspresikannya dalam bentuk puisi. Sejak kecil anak-anak pada umumnya telah diajar dan diperkenalkan dengan Tuhan, dengan keyakinan keagamaan, dan hal ternyata mampu menyentuh jiwa mereka. Anak-anak telah menyadari bahwa ada kekuatan lain yang bahkan tiada banding yang dapat dijadikan muara segala doa dan permohonan, yaitu Tuhan Yang Mahaesa. Lewat doa dan permohonan itulah kemudian anak-anak mencoba membantu dan berempati kepada orang lain.

Masih ada sejumlah makna lain yang ditemukan dalam puisi-puisi anak yang frekuensi pemunculannya relatif sedikit yang kemudian dikategorikan ke dalam makna lainlain, yaitu antara lain hal-hal yang berkaitan dengan masalah menabung, kejujuran, ulang tahun, lomba mewarnai, minum susu, pertemanan, cermin, peminta-minta, dan lainlain. Berbagai makna tersebut dirasa tidak perlu lagi dibahas satu per satu karena pembahasan di atas tampaknya telah cukup menggambarkan bagaimana keadaan berbagai makna yang banyak diangkat ke dalam puisi. Satu hal yang pasti adalah dengan semakin banyaknya makna yang diungkap menunjukkan bahwa pemikiran anak pun sudah menjangkau permasalahan kehidupan yang lebih luas. Terhadap maknamakna tertentu yang frekuensi pemunculannya tinggi, hal itu menunjukkan bahwa masalahmasalah itu menjadi obsesi banyak anak, menyentuh jiwa, dan mendorong mereka untuk mengekspresikannya ke dalam bentuk puisi. 
Artinya, ada hal atau masalah kehidupan yang sama-sama mendapat penyikapan anak secara bersama walau dalam menyikapinya berbeda.

Dilihat dari segi nilai kepuitikan, selain sejumlah puisi tampak cukup bagus, juga tidak dapat diingkari masih tidak sedikit puisi yang tampak kurang terolah dengan baik terutama dalam hal pemilihan kata. Selain itu, juga banyak terlihat nada-nada puisi yang sepertinya menggurui pembaca walau maunya si bocah penulisnya adalah merupakan sebuah ajakan. Hal itu tampaknya masih wajar terjadi mengingat di sekolah atau di rumah anak-anak masih sering secara langsung digurui oleh guru dan orang tua sehingga mereka mengekspresikannya ulang begitu saja. Hal itu menunjukkan bahwa masih polos dan lugasnya jiwa dan cara berpikir mereka. Namun, kesemuanya itu, sungguh, menjadi kurang berarti jika dibandingkan kenyataan bahwa anak-anak yang benar-benar masih bocah itu sudah mampu menulis puisi yang demikian. Jika hal itu terpupuk dengan baik, tidak mustahil jika sejumlah di antaranya akan tetap bertahan menjadi puisi yang berbobot kelak.

\section{PENUTUP}

Puisi merupakan salah satu sarana untuk bereskpresi, tidak peduli oleh orang dewasa atau anak-anak. Kajian ini menunjukkan bahwa anak-anak pun, bahkan yang masih berusia TK, sudah mampu mempergunakan puisi sebagai sarana berekspresi itu. Tema dan atau makna yang diungkapkan umumnya masih mencerminkan dunia ke-bocah-an sesuai dengan perkembangan kejiwaan dan pengalaman mereka. Makna yang diungkap sudah begitu beragam, namun yang dominan masih saja halhal yang berada di sekitar anak, hal-hal yang paling menyentuh jiwa anak, terutama masalah alam sekitar, binatang, dan orang tua dan guru. Tampaknya, tidak berlebihan jika dikatakan bahwa kemampuan anak-anak berpuisi di atas dapat memberikan angin segar bagi perkembangan kesastraan di Indonesia, tidak saja sastra anak, tetapi juga sastra dewasa karena mereka, para pengarang anak itu, kelak juga bakal menjadi orang dewasa.

\section{DAFTAR PUSTAKA}

Huck, Charlotte S, Susan Hepler, dan Janet Hickman. 1987. Children's Literature in The Elementary School. New York: Holt, Rinehart and Winston.

Lukens, Rebecca J. 2003. A Critical Handbook of Children's Literature. New York: Longman.

Mitchell, Diana. 2003. Children's Literature, an Invitation to the World. Boston: Ablongman.

Nurgiyantoro, Burhan. 2005. Sastra Anak, Pengantar Pemahaman ke Dunia Anak. Gadjah mada University Press.

Saxby, Maurice. 1991. "The Gift Wings: The Value of Literature to Children", dalam Maurice Saxby \& Gordon Winch (eds). Give Them Wings, The Experience of Children's Literature, Melbourne: The Macmillan Company, hlm. 3\%118.

Winch, Gordon. 1991. "The Light in The Eye: on Good Books for Children", dalam Maurice Saxby \& Gordon Winch (eds). Give Them Wings, The Experience of Children's Literature, Melbourne: The Macmillan Company, hlm. 19\%125. 